\title{
Stoichiometric Characteristics of Soil in Several Different Communities
}

\author{
Xinyu Liu ${ }^{1}$, Shengxiu $\mathrm{Li}^{1}$, Fang Luo $^{1,2^{*}}$, Yan Ning ${ }^{1}$, Biao Huang ${ }^{1}$, Fan Yang ${ }^{1}$ \\ ${ }^{1}$ School of Water Conservancy and Environment, University of Jinan, 250022 Jinan, China \\ ${ }^{2}$ Shandong Provincial Engineering Technology Research Center for Ecological Carbon Sink and Capture Utilization, 250022 Jinan, \\ China
}

\begin{abstract}
The content of nitrogen, phosphorus, potassium and organic matter in soil is an important index to determine soil nutrient status. In this paper, the contents of nitrogen, phosphorus, potassium, organic matter and soil salt in the soil of several different plant communities in the campus were measured by the chemical measurement characteristics of several different communities in University of Jinan. The differences in the measurement characteristics of soil chemical measurement in different plant communities were analyzed. The results showed that the highest organic matter content in several communities was Cherry Blossom community, $76.33 \mathrm{mg} / \mathrm{kg}$, and the highest ammonium nitrogen content was $196.08 \mathrm{mg} / \mathrm{kg}$; the highest content of available phosphorus was the community of Begonia, $168.14 \mathrm{mg} / \mathrm{kg}$, and the highest content of available potassium was the community of Robinia pseudoacacia, which was the highest salt content in $64.99 \mathrm{mg} / \mathrm{kg}$ soil. The community of cherry blossoms is $569 \mu \mathrm{s}$. There was little difference in soil organic matter, available phosphorus and available potassium in different plant communities..
\end{abstract}

\section{Introduction}

Soil is the mechanical support and material foundation for plant growth, and its fertility directly reflects the ability of land to provide nutrients for plant growth. The contents of nitrogen, phosphorus, potassium and organic matter in soil are important indexes for determining soil nutrient status[1]. The content of organic matter directly affects the physical and chemical properties and physiological activities of the soil, and it is the decisive factor to reflect the soil fertility and the characteristics of supplying fertilizer[2]. Determination of nitrogen, phosphorus and potassium in soil is great significant to soil fertility. A large number of elements such as nitrogen, phosphorus and potassium are indispensable for plant growth and development. Although the amount of crops required for these elements varies greatly, they are equally important for crop growth and development and must not be substituted for each other. The stoichiometric characteristics of nitrogen, phosphorus and potassium reflect the plant's own characteristics and its long-term adaptation to the growth environment[3]. Studying the differences in the chemical measurement characteristics of several different communities in the main campus of University of Jinan could better understand the nutrient components of various soil in the campus, and provide reference for the landscaping and beautifying of the campus.

\section{Materials and methods}

\footnotetext{
* Corresponding author: stu_luof@ujn.edu.cn
} 
Table 1. Community location and environment.

\begin{tabular}{|c|c|c|c|}
\hline $\begin{array}{c}\text { Plant } \\
\text { community }\end{array}$ & Latin name & location & $\begin{array}{l}\text { Ventila } \\
\text { tion }\end{array}$ \\
\hline $\begin{array}{c}\text { Cherry } \\
\text { blossoms A }\end{array}$ & $\begin{array}{l}\text { Cerasus sp. } \\
\text { community }\end{array}$ & $\begin{array}{l}\text { A little further from } \\
\text { the building }\end{array}$ & Good \\
\hline $\begin{array}{c}\text { Cherry } \\
\text { blossoms B }\end{array}$ & $\begin{array}{l}\text { Cerasus sp. } \\
\text { community }\end{array}$ & $\begin{array}{l}\text { Next to Information } \\
\text { Building }\end{array}$ & Poor \\
\hline Begonia A & $\begin{array}{l}\text { Malus } \\
\text { micromalus } \\
\text { community }\end{array}$ & $\begin{array}{l}\text { Qinglong Mountain } \\
\text { near the road }\end{array}$ & Good \\
\hline Begonia B & $\begin{array}{l}\text { Malus } \\
\text { micromalus } \\
\text { community }\end{array}$ & Qinglong Mountain & Poor \\
\hline $\begin{array}{c}\text { locust } \\
\text { community } \\
\text { A }\end{array}$ & $\begin{array}{c}\text { Robinia } \\
\text { pseudoacacia }\end{array}$ & $\begin{array}{l}\text { Qinglong Mountain } \\
\text { near the road }\end{array}$ & Good \\
\hline $\begin{array}{c}\text { locust } \\
\text { community } \\
\text { B }\end{array}$ & $\begin{array}{c}\text { Robinia } \\
\text { pseudoacacia }\end{array}$ & $\begin{array}{c}\text { Qinglong Mountain } \\
\text { with Large areas of } \\
\text { roses(Rosa multiflora) } \\
\text { and spring } \\
\text { flowers(Jasminum } \\
\text { nudiflorum Lindl) }\end{array}$ & Poor \\
\hline
\end{tabular}

\section{Discussion and results}

\subsection{Organic matter}

Organic matter content is an important basis for judging soil fertility, and the important index for evaluating soil quality is the basis for determining soil fertility. As can be seen from table 1, among the six communities, the highest content of organic matter is the cherry blossom A, 76.33 per thousand, and the lowest is locust community A, 41.63 per thousand. The mean value of organic matter in the 6 communities was 53.87 per thousand, the standard deviation was 12.41, and the coefficient of variation was 4.34 , indicating that there was little difference in soil organic matter content between the 6 communities. ( Table 2 and Fig. 1.)

Table 2. Soil organic matter content in six communities.

\begin{tabular}{|c|c|}
\hline Plant community & $\begin{array}{c}\text { soil organic matter } \\
\text { content\%o }\end{array}$ \\
\hline Cherry blossoms A & 76.33 \\
\hline Cherry blossoms B & 52.2 \\
\hline Begonia A & 49.06 \\
\hline Begonia B & 45.57 \\
\hline locust community A & 41.63 \\
\hline locust community B & 58.42 \\
\hline
\end{tabular}

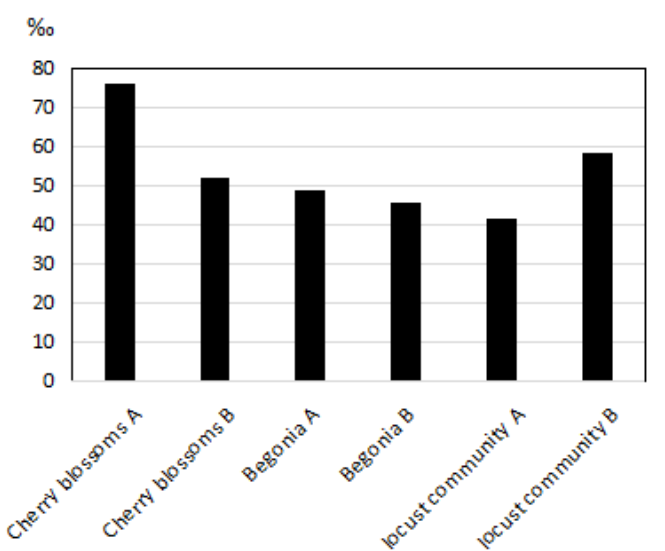

Fig. 1. Soil organic matter content in six communities.

From Fig.1, we can see that the difference between the two Begonia communities is not significant, while the difference between the two cherry blossoms and the locust communities is large.

\subsection{Ammonium nitrogen}

The content of nitrogen plays a decisive role in the growth and development of plants. The total nitrogen content is an important indicator of soil nitrogen supply[4-6]. The ammonium nitrogen in the soil can be adsorbed by the soil colloid, is exchangeable ammonium nitrogen fertilizer, can also be dissolved in the soil solution, can be directly absorbed by plants and belongs to the available nitrogen. Usually, the content of ammonium nitrogen in soil is $1.4 \sim 30 \mathrm{mg} / \mathrm{kg}$. The highest content of ammonium nitrogen is the Begonia community, $196.08 \mathrm{mg} / \mathrm{kg}$, the lowest is cherry blossom A community, $62.53 \mathrm{mg} / \mathrm{kg}$. The mean value of ammonium nitrogen is $120.12 \mathrm{mg} / \mathrm{kg}$, the standard deviation is 52.76 , and the coefficient of variation is 0.44 , which indicates that the content of ammonium nitrogen in the 6 communities is quite different.( Table 3 and Fig.2.)

\subsection{Available phosphorus}

Available phosphorus refers to phosphorus that is easily absorbed and utilized by plants in the soil. Soil available phosphorus is the most effective part of soil available phosphorus storage, and is also an important index for evaluating the phosphorus supply level of soil. The available phosphorus of these different communities in the campus is between $60 \sim 170 \mathrm{mg} / \mathrm{kg}$, the highest content of available phosphorus is the community of Begonia B, $168.14 \mathrm{mg} / \mathrm{kg}$, the lowest is the locust community A , which is $64.74 \mathrm{mg} / \mathrm{kg}$. The average of available phosphorus was $123.82 \mathrm{mg} / \mathrm{kg}$, the standard deviation was 35.50 , and the coefficient of variation was 0.29 , indicating that there was little difference in soil available phosphorus between the six communities.( Table 3 and Fig.2.) 
Table 3. Soil N, P and K content in six communities.

\begin{tabular}{|c|c|c|c|}
\hline $\begin{array}{c}\text { Plant } \\
\text { community }\end{array}$ & $\begin{array}{c}\text { Ammoni } \\
\text { um } \\
\text { nitrogen } \\
\mathrm{mg} / \mathrm{kg}\end{array}$ & $\begin{array}{c}\text { soil Available } \\
\text { phosphorusmg } \\
/ \mathrm{kg}\end{array}$ & $\begin{array}{c}\text { soil Quick } \\
\text { acting } \\
\text { potassium } \\
\mathrm{mg} / \mathrm{kg}\end{array}$ \\
\hline $\begin{array}{c}\text { Cherry } \\
\text { blossoms A }\end{array}$ & 83.00 & 126.93 & 8.74 \\
\hline $\begin{array}{c}\text { Cherry } \\
\text { blossoms B }\end{array}$ & 62.53 & 150.30 & 7 \\
\hline Begonia A & 196.08 & 112.80 & 24.32 \\
\hline Begonia B & 113.64 & 168.14 & 6.87 \\
\hline $\begin{array}{c}\text { locust } \\
\text { community A }\end{array}$ & 93.38 & 64.74 & 64.99 \\
\hline $\begin{array}{c}\text { locust } \\
\text { community B }\end{array}$ & 172.06 & 120.02 & 8.56 \\
\hline
\end{tabular}

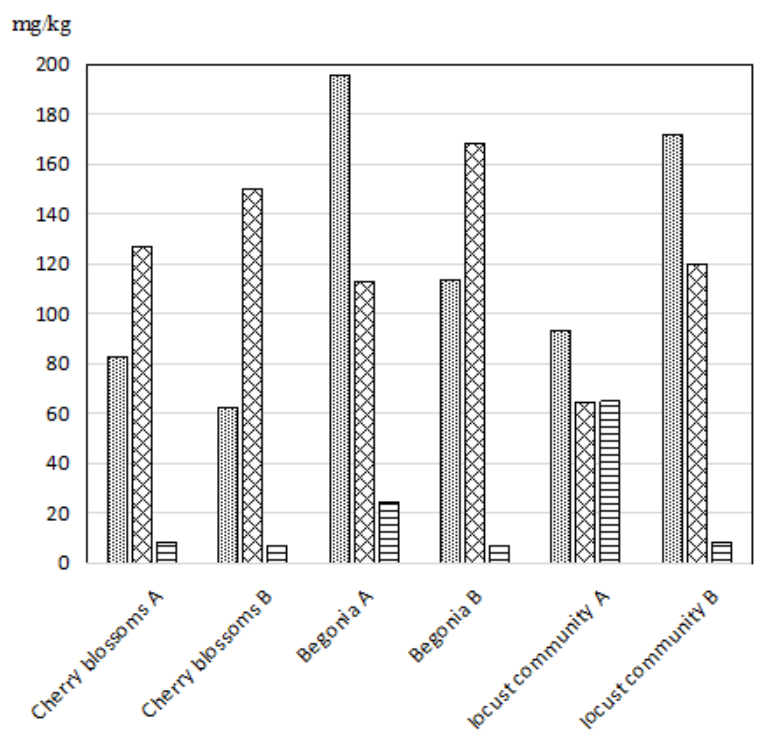

图 soil Ammonium nitrogen $\square$ soil Available phosphorus $\boxminus$ soil Quick acting potassium

Fig. 2. Soil N, P and K content

\subsection{Quick acting potassium}

Quick acting potassium refers to potassium which is easily absorbed and utilized by crops in soil. It includes potassium in soil solution and exchangeable potassium in soil. The content of available potassium is one of the most important indicators of soil potassium supply. The content of available potassium in several communities is $6 \sim 65$, which is lower than that in normal soil. The highest content of available potassium was locust community A, $64.99 \mathrm{mg} / \mathrm{kg}$, the lowest was the community of Begonia B , $6.87 \mathrm{mg} / \mathrm{kg}$. The average of available potassium was $20.08 \mathrm{mg} / \mathrm{kg}$, the standard deviation was 22.99 , and the coefficient of variation was 1.14 , indicating that there was little difference in soil available potassium between the six communities.( Table 3 and Fig.2.)

\subsection{Salinity}

Soil salt content is the percentage of soil salt content (mainly chloride, sulphate, carbonate) in dry soil. Electrical conductivity is the conductivity of material, and the electrical conductivity of soil is obtained by inserting instruments into soil solution. The more salt content in soil, the conductivity is stronger and greater. The electrical conductivity of soil in these communities is relatively stable, which is between 390 570. The highest salt content was Cherry Blossom B community, $569 \mu \mathrm{s}$, and the lowest was the community of Begonia B, which was $393 \mu \mathrm{s}$. The mean soil salinity was $471.50 \mu \mathrm{s}$, the standard deviation was 72.17 , and the coefficient of variation was 0.15 , indicating that the soil salt content of these six communities was quite different.( Table 4 and Fig.3.)

Table 4. Soil salinity content in six communities.

\begin{tabular}{|c|c|}
\hline Plant community & $\begin{array}{c}\text { soil salinity } \\
\text { content }(\mu \mathrm{s})\end{array}$ \\
\hline Cherry blossoms A & 548 \\
\hline Cherry blossoms B & 569 \\
\hline Begonia A & 409 \\
\hline Begonia B & 393 \\
\hline Robinia pseudoacacia A & 461 \\
\hline Robinia pseudoacacia B & 449 \\
\hline
\end{tabular}

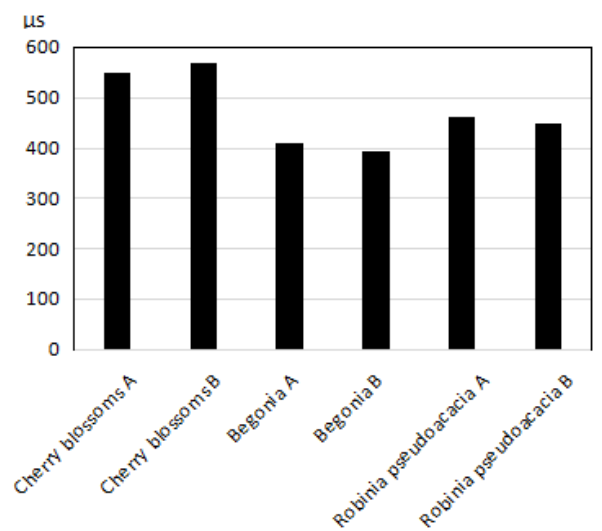

Fig. 3. Soil salinity content

\subsection{Comparison of different communities}

The merging of six communities into three types is shown in Table5. As can be seen from Table 5, the content of organic matter is: Cherry Blossom > Robinia pseudoacacia > begonia; the content of ammonium nitrogen: Begonia $>$ Robinia pseudoacacia $>$ cherry blossom; the content of quick acting phosphorus: Haitang $>$ Cherry Blossom $>$ Robinia pseudoacacia; the content of available potassium: Robinia pseudoacacia $>$ Begonia > cherry; salt content: Cherry $>$ Robinia $>$ Begonia. 
Table 5. Chemometrics of soil in different communities

\begin{tabular}{|c|c|c|c|c|c|}
\hline $\begin{array}{c}\text { Plant } \\
\text { community }\end{array}$ & $\begin{array}{c}\text { Organic } \\
\text { matter } \\
\text { content } \\
(\%)\end{array}$ & $\begin{array}{c}\text { Ammoni } \\
\text { um } \\
\text { nitrogen } \\
(\mathrm{mg} / \mathrm{kg})\end{array}$ & $\begin{array}{c}\text { Available } \\
\text { phosphor } \\
\text { us } \\
(\mathrm{mg} / \mathrm{kg})\end{array}$ & $\begin{array}{c}\text { Quick } \\
\text { acting } \\
\text { potassiu } \\
\mathrm{m} \\
(\mathrm{mg} / \mathrm{kg})\end{array}$ & $\begin{array}{c}\text { Salinity } \\
(\mu \mathrm{s})\end{array}$ \\
\hline $\begin{array}{c}\text { Cherry } \\
\text { blossom }\end{array}$ & 64.265 & 72.77 & 138.62 & 7.87 & 558.5 \\
\hline $\begin{array}{c}\text { Begonia } \\
\text { locust } \\
\text { communit } \\
\mathrm{y}\end{array}$ & 47.315 & 154.86 & 140.47 & 15.595 & 401 \\
\hline
\end{tabular}

On the whole, the content of organic matter in soil of different communities is not different. According to the $\mathrm{N}$, $\mathrm{P}$ and $\mathrm{K}$ content of soil in different communities, the nutritional level of soil of locust community and Begonia community was higher than that of cherry blossom community.

\section{Conclusion}

In this study, the soil organic matter, ammonium nitrogen, available phosphorus, available potassium and soil salt content in several different plant communities on campus were measured. The results showed that the content of organic matter in the soil of these communities was less. It should be properly fertilized to improve the content of soil organic matter and improve the physical and chemical properties of soil. Ammonium nitrogen content is higher than normal value, and the supply level of ammonium nitrogen in soil is high enough to meet the needs of plant growth and development. The content of available phosphorus is relatively normal and the content of available potassium is low, and the cherry blossom community is the lowest, which indicates that its growth and development require less potassium content. In addition, the content of available potassium in two locust communities is quite different. There is no significant difference in soil salinity between these communities.

\section{References}

1. Y. Su, Shelterbelt Science and Technology, 1 (2018)

2. R.Y. Jiang, J.K. Wang, Y.M. An,Anhui Agricultural Science, 41 (2013), pp. 1473-1474

3. C. Guo, B. Tuo, J. Applied Ecology, 29(2018):380388

4. P. Wen, S.L. Wen, J. Gansu Agricultural University, 28(1993):313-316

5. Y.P. Chen, J.B. Xia, soil bulletin, 48(2017):392-398

6. S.Q. Wang, G.R. Yu, Acta Ecologica Sinica, 28(2008):3937-3947 